\title{
INVASIVE LOBULAR CARCINOMAS TREATED AT HOSPITAL DE CLÍNICAS OF UFPR: INCIDENCE, CHARACTERISTICS AND CLINICAL OUTCOME
}

\author{
Carcinomas lobulares invasores de mama tratados no Hospital \\ de Clínicas da UFPR: incidência, características e evolução clínica
}

\author{
Anaí Caroline Hamann Gasperin*, Gabriela Romaniello1, Isabella Naomi Furuie1, \\ Maria Júlia Jorge Mauro¹, Thayane Guimarães de Melo, Plínio Gasperin Júnior ${ }^{1}$, Vinicius Milani Budel ${ }^{1}$
}

\section{ABSTRACT}

Objective: The aim of this study is to depict the clinical and epidemiological profile of patients treated for invasive lobular carcinoma (ILC) at Hospital das Clínicas of Universidade Federal do Paraná (HC-UFPR) over the course of ten years and to evaluate the variation of ILC dimensions on imaging exams by comparing them to real-size lesions identified in surgical specimens. Methods: Patients undergoing breast surgical procedures at HC-UFPR from 2005 to 2014 were selected. Out of these, 36 were diagnosed with ILC and had their medical files sought after clinical, epidemiological, therapeutic and prognosis characteristics. The variance of tumor sizes in imaging methods and anatomopathological descriptions were also studied. Results: Patients' mean age at diagnosis was 59.6 years. Most of them were classified as clinical stages II (40\%) and III (26.7\%) by the time they were diagnosed. The majority of tumors were HER2 negative (77.2\%) and estrogen-receptor positive (90\%). The surgical treatment was radical in $74.2 \%$ of the cases. $31.4 \%$ of the patients underwent both mammography and ultrasonography screening and $45.7 \%$ underwent only one of them. None of the patients were submitted to magnetic resonance imaging (MRI). Conclusion: Data found about patients with invasive lobular carcinoma at HC-UFPR is in accordance with the medical literature, including incidence rates and tumor characteristics. The variance of tumor sizes in imaging exams and surgical specimen was not statistically significant.

KEYWORDS: lobular carcinoma; breast neoplasms; histology; ductal carcinoma; medullary carcinoma.

\section{RESUMO}

Objetivo: O estudo busca caracterizar o perfil clínico epidemiológico referente às pacientes tratadas por carcinoma lobular invasor de mama (CLI) no Hospital de Clínicas da Universidade Federal do Paraná (HC-UFPR) em um período de dez anos e avaliar as variações das dimensões dos CLI nos exames de imagem quando comparadas ao real tamanho das lesões identificadas nas peças de anatomia patológica. Métodos: Foram selecionadas pacientes submetidas a procedimentos cirúrgicos de mama no HC-UFPR entre os anos de 2005 e 2014, dentre as quais 36 apresentaram diagnóstico de CLI. Seus prontuários foram analisados para avaliação de características clínicas, epidemiológicas, terapêuticas e prognósticas. Também foi avaliada a discrepância dos valores de tamanho do tumor em métodos de imagem em relação ao descrito nos laudos anatomopatológicos. Resultados: As pacientes com diagnóstico de CLI tinham média de idade no diagnóstico de 59,6 anos. O diagnóstico foi feito, em sua maioria, nos estádios clínicos II (40\%) e III (26,7\%). Houve maior negatividade (77,2\%) para HER2 e positividade (90\%) para receptor de estrógeno. O tratamento cirúrgico foi radical em $74,2 \%$ das pacientes. Em exames de imagem, 31,4\% das pacientes realizaram mamografia e ultrassonografia em conjunto, 45,7\% fizeram apenas um dos exames e nenhuma realizou ressonância magnética. Conclusão: Observou-se que a casuística de patologias mamárias do HC-UFPR está de acordo com a literatura em relação à incidência e às características próprias dos CLI. A análise da discrepância dos tamanhos dos tumores em exames de imagem em relação às peças cirúrgicas não obteve resultados significativos estatisticamente.

PALAVRAS-CHAVE: carcinoma lobular; neoplasias da mama; histologia; carcinoma ductal; carcinoma medular.

Study carried out at Hospital de Clínicas of Universidade Federal do Paraná - Curitiba (PR), Brazil.

${ }^{1}$ Hospital de Clínicas, Universidade Federal do Paraná - Curitiba (PR), Brazil.

*Corresponding author: anai.gasperin@hotmail.com

Conflict of interest: nothing to declare.

Received on: 02/01/2018. Accepted on: 07/13/2018 


\section{INTRODUCTION}

Breast cancer, excluding non-melanoma skin cancer, is the most common neoplasm among women around the world and also the one presenting the highest mortality rate ${ }^{1}$. According to the National Cancer Institute (INCA), breast cancer was the most common among females in 2016, with estimated 57,960 new cases that year ${ }^{2}$. Most of them are placed in the category of invasive breast cancer, which is typically classified according to histology as invasive ductal carcinoma, the most frequent type and accounting for about $75 \%$ of all cases, and as special subtype of breast carcinoma, mainly represented by invasive lobular carcinoma (ILC) ${ }^{3}$. Although these are within the same disease's spectrum, there is an undeniable heterogeneity between the mentioned entities. Such differences are related to risk factors, clinical presentation and prognosis, as they vary according to subtypes of invasive breast carcinomas ${ }^{4}$.

ILC contributes with about 10 to $15 \%$ of all cases of breast cancer in the West, and its incidence increased significantly from the 1970s to the 2000s. Postmenopausal hormone replacement therapy has been identified as the primary cause of this increase, while the improvement in methods of detection has a supportive role in this scenario ${ }^{3}$. With the decrease in indications for hormone therapy at the beginning of the millennium, the reduction in ILC incidence occurred paralle ${ }^{5,6}$. However, since 2004, the number of cases has increased again for reasons not yet elucidated ${ }^{7.8}$.

Some of the major risk factors linked to the development of ILC are: advanced age at first child delivery, late menopause, and postmenopausal hormone replacement therapy. Positive family history of malignancy in first-degree relatives also poses an increased risk of developing ILC in life $\mathrm{f}^{9-12}$.

Clinically, when compared to the non-special type of breast carcinoma, ILC presents as a larger, well-differentiated tumor at diagnosis in patients with advanced age, being frequently associated with multifocality and positive lymph node involvement, with typical molecular profile positive for estrogen receptors (ER) and negative for HER $2^{13-15}$.

Histologically, the disease is characterized by small, uniform cells grouping that invade the breast stroma in a linear clustering pattern, also referred to as "in-line" clustering. These characteristics increase technical difficulty to detect ILC upon physical examination, mammography and other imaging methods available for screening and diagnosis of breast cancer. For this reason, a much larger tumor is often found upon surgical treatment or pathological anatomy compared to what has been predicted by previous imaging tests ${ }^{16}$. In order to reduce this type of unexpected findings during surgeries, more accurate imaging tests such as magnetic resonance imaging (MRI) are recommended in surgical planning for ILC patients ${ }^{17}$.

Despite the technical difficulties to early diagnose lobular carcinomas by imaging methods, the survival and disease-free time in ILC was shown to be similar or better compared to breast ductal carcinomas, in addition to many studies indicating lower rates of local recurrence in the special subtype of breast carcinoma ${ }^{16,18}$.

This study tries and depicts the clinical and epidemiological characteristics of patients treated for ILC at Hospital de Clinicas of Universiade Federal University do Paraná (HC-UFPR) over a period of 10 years, aiming to identify patterns and peculiarities of its manifestation, which has presented several variations of incidence and profile over the decades. In addition, variations in ILC dimensions upon imaging examinations and compared to the real size of lesions identified in post-surgical pieces of pathological anatomy are also analyzed.

\section{METHODS}

Patients submitted to breast surgical procedures at the HC-UFPR between 2005 and 2014 were retrospectively selected. The eligibility criteria were: females of all ages submitted to breast surgery of any nature at the HC-UFPR in the period established. Patients who underwent breast procedures with esthetic purposes or did not meet all inclusion criteria were excluded. All cases of breast lesions found in biopsy records of the HC-UFPR Pathology Service from 2005 to 2014 were evaluated for patient selection. Reports were then assessed case by case to maintain the epidemiological records of the case series in the hospital and in search for cases of ILC.

There were 1,501 cases of breast lesions in the period, with their anatomopathological reports recorded in spreadsheet. Among these cases, 36 were ILC, one of the patients being excluded from due to absence of medical records at the Medical Archive Service; 35 cases of ILC were selected. These patients had their charts analyzed for detailed data collection and evaluation of tumor specific characteristics, family and past history, therapeutic approach, clinical evolution and survival. Discrepancies in tumor size found in mammography, ultrasonography (US) or MRI compared to the size described in pathological anatomy reports were also evaluated.

Tumor size was determined by its larger diameter when more than one dimension was described. Disease-free interval (DFI) and survival rates post-treatment were used as a parameter to assess patient survival. The DFI was calculated from day of diagnosis to day of first recurrence, while survival after treatment comprised the period until the last visit. Over the 10 years studied, the service lost eight patients to follow-up, and their DFI and survival rate were calculated based on the date of their last visit. All data collected were input to an Excel' 2013 spreadsheet.

The software R DEVELOPMENT CORE TEAM" was used for statistical analysis and inferential statistics tests applied were Kruskal-Wallis test and Spearman's correlation, with results considered statistically significant when $p \leq 0.05$. The study was approved by the Research Ethics Committee of HC-UFPR. 


\section{RESULTS}

The epidemiological analysis of this breast cancer case series of HC-UFPR showed that, from 1,501 cases recorded between 2005 and 2014, 908 (60.5\%) had benign findings at biopsy and 593 (39.5\%) tested positive for malignancy. From malignancy cases, 505 (85.01\%) were invasive ductal carcinomas, 36 (6.07\%) were ILC and 20 (3.37\%) were mixed carcinomas. Results are detailed in Graph 1.

Patients diagnosed with ILC had mean age of 59.6 years at diagnosis, mean age of menarche of 12.75 years, mean age of menopause of 47.59 years, mean number of children of 2.2 and negative family history for breast cancer in most cases (77.1\%). The diagnosis was mainly concluded at clinical stages II (40\%) and III (26.7\%). The full set of results regarding the profile of patients are compiled in Table 1 . As for the molecular characteristics of ILC tumors, $77.1 \%$ of cases were HER 2 negative $(0+$ and $1+$ ), but progesterone (PR) and estrogen (ER) receptors were positive in most cases (70 and 90\%, respectively). Radical mastectomy was the surgical procedure of choice for most patients $(74.2 \%)$, clinical therapy with hormone therapy was indicated in $71.4 \%$ of cases and radiotherapy was applied in 60\%. Tumor characteristics are listed in Table 2 and types of treatments are shown in Table 3.

Regarding the imaging tests used, $31.4 \%$ of the patients were submitted to mammography and US in combination, with most patients performing only one of the exams (45.7\%). No patients included in the study had been submitted to MRI. Results on imaging tests are shown in Table 4. Inferential statistics was analyzed by correlation of survival after treatment against clinical stage (Graph 2A) and DFI against clinical stage (Graph 2B), with statistically significant results in both instances. Post-treatment survival versus tumor size upon pathologic biopsy (Graph 3A), DFI versus tumor size upon pathologic biopsy (Graph 3B), and tumor size at imaging versus tumor size upon pathologic biopsy (Graph 4) were not statistically significant.

\section{DISCUSSION}

The increase in incidence of ILC, as well as its clinical and therapeutic peculiarities require further studies like this one, aiming to evaluate its characteristics not only to improve understanding about its pathology, but also to help establish specific strategies to approach patients.

Of 596 biopsies positive for malignancy in the service, 36 resulted in ILC, totaling $6.07 \%$ of all cases. The prevalence of cases treated is consistent with the literature, which predicts a contribution of about $10 \%$ of breast malignancies by ILC, ranging from 5 to $15 \%$ in the series reported ${ }^{4}$.

Mean age at diagnosis of ILC in patients studied was 59.6 years, which is consistent with previous reports stating that CLI predominantly affects patients aged 50 years or more ${ }^{15}$. The common involvement of menopausal patients is suggested to be associated with the lower aggressiveness of lobular lesions, whose proliferative indexes are usually low and postpone clinical manifestations $^{19}$. Another hypothesis considered is that these patients would be more affected due to the late diagnosis of lobular lesions, as these are more difficult to perceive through screening imaging ${ }^{20}$.

Positive family history of breast cancer was present in $22.9 \%$ of cases. In contrast, a study conducted in 2015 on 135 cases of ILC reported only $4.5 \%$ of cases with positive family history ${ }^{21}$. This difference is possibly related to the small number of cases assessed in our study, leading to a biased sample.

The quadrant of the breast most affected by ILC was superexternal (41.9\%), which is consistent with other reports in the literature and classically attributed to the fact that it is the region of the breast with the highest concentration of mammary parenchyma, thus more prone to disease occurrence ${ }^{22}$.

The most common clinical stages found in our study were II (40\%) and III (26.7\%), and the initial stages (I and II) together accounting for $50 \%$ of the cases. Another Brazilian study obtained similar results, with $57 \%$ of cases diagnosed in initial clinical stages $^{23}$. However, international studies have shown a much more significant incidence of diagnoses at early clinical stages, suggesting a better and more comprehensive screening system ${ }^{22}$.

\section{Overall incidence}
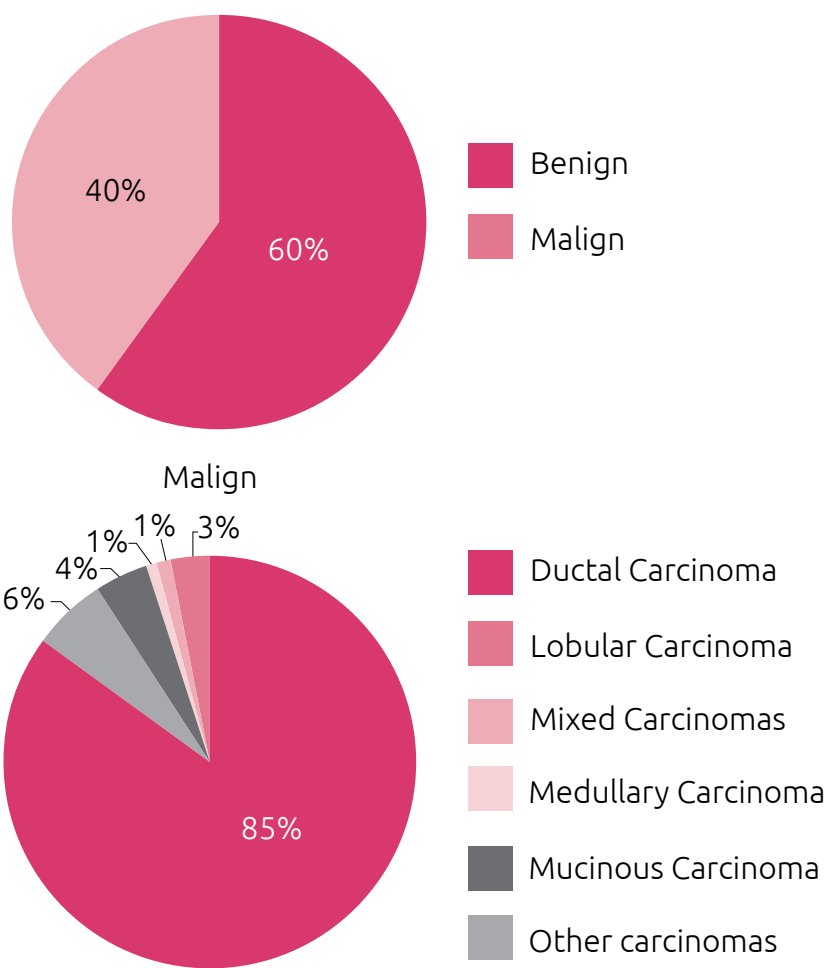

Incidence of cases of breast cancer treated at HC-UFPR between 2005 and 2014. Graph 1. Incidence of cases of breast neoplasms treated at HC-UFPR. 
Table 1. Profile of patients with invasive lobular carcinoma.

\begin{tabular}{|c|c|c|c|}
\hline & $\begin{array}{l}\text { Absolute } \\
\text { frequency }\end{array}$ & $\begin{array}{c}\text { Relative } \\
\text { frequency (\%) }\end{array}$ \\
\hline \multirow{2}{*}{$\begin{array}{l}\text { Breast cancer } \\
\text { Family history* }\end{array}$} & Positive & 8 & 22.9 \\
\hline & Negative & 27 & 77.1 \\
\hline \multirow{2}{*}{$\begin{array}{l}\text { Associates } \\
\text { systemic } \\
\text { diseases** }\end{array}$} & Yes & 18 & 51.4 \\
\hline & No & 17 & 48.6 \\
\hline \multirow{3}{*}{ Laterality } & Right & 17 & 50.0 \\
\hline & Left & 13 & 38.2 \\
\hline & Bilateral & 4 & 11.7 \\
\hline \multirow{6}{*}{$\begin{array}{l}\text { Breast } \\
\text { quadrant*** }\end{array}$} & UOQ & 13 & 41.9 \\
\hline & UIQ & 2 & 6.4 \\
\hline & ISQ & 2 & 6.4 \\
\hline & IIQ & 2 & 6.4 \\
\hline & Central & 5 & 16.1 \\
\hline & $\begin{array}{l}\text { More than } \\
\text { one local }\end{array}$ & 7 & 22.5 \\
\hline \multirow{4}{*}{ Clinical stage } & 1 & 3 & 10.0 \\
\hline & 2 & 12 & 40.0 \\
\hline & 3 & 8 & 26.7 \\
\hline & 4 & 7 & 23.3 \\
\hline
\end{tabular}

General clinical data and previous history of patients with invasive lobular carcinoma of the breast treated at HC-UFPR between 2005 and 2014. *Only first-degree relatives were considered for family history; **systemic diseases considered were systemic arterial hypertension (SAH), diabetes mellitus (DM), obesity, smoking, alcoholism and thyroid disorders; ***UOQ: upper-outer quadrant, UIQ: upper-inner quadrant, ISQ: infero-sternal quadrant, IIQ: infero-internal quadrant.

Table 2. Tumor characteristics.

\begin{tabular}{l|c|c|c}
\multicolumn{1}{c|}{} & $\begin{array}{c}\text { Absolute } \\
\text { frequency }\end{array}$ & $\begin{array}{c}\text { Relative } \\
\text { frequency (\%) }\end{array}$ \\
\cline { 2 - 4 } & 0 & 24 & 68.6 \\
\cline { 2 - 4 } & $1+$ & 3 & 8.6 \\
\cline { 2 - 4 } & $2+$ & 6 & 17.1 \\
\hline \multirow{3}{*}{ HER* } & $3+$ & 2 & 5.7 \\
\hline \multirow{3}{*}{ PR** } & Positive & 27 & 90.0 \\
\cline { 2 - 4 } & Negative & 3 & 10.0 \\
\cline { 2 - 4 } & Positive & 21 & 70.0 \\
\hline
\end{tabular}

Molecular characteristics of invasive lobular carcinoma of the breast treated at HC-UFPR between 2005 and 2014; *ER: estrogen receptor; **PR: progesterone receptor

As to the molecular characteristics of tumors, the classical profile of hormone receptor positivity and HER2 negativity was predominant. The literature suggests that ILC that differ from this pattern are associated with worse prognosis, which was not evaluated in our study, since only two cases were HER2-positive $e^{15}$.
Table 3. Treatment.

\begin{tabular}{l|c|c|c}
\multirow{2}{*}{$\begin{array}{l}\text { Surgical } \\
\text { treatment }\end{array}$} & $\begin{array}{c}\text { Absolute } \\
\text { frequency }\end{array}$ & $\begin{array}{c}\text { Relative } \\
\text { frequency (\%) }\end{array}$ \\
\cline { 2 - 4 } & Conservative & 8 & 25.8 \\
\hline \multirow{3}{*}{$\begin{array}{l}\text { Axillary } \\
\text { approach }\end{array}$} & $\begin{array}{c}\text { Sentinel } \\
\text { lymph node }\end{array}$ & 6 & 74.2 \\
\cline { 2 - 4 } & $\begin{array}{c}\text { Axillary } \\
\text { emptying }\end{array}$ & 17 & 22.2 \\
\cline { 2 - 4 } & Both & 4 & 62.9 \\
\hline \multirow{2}{*}{\begin{tabular}{l} 
Chemotherapy \\
\cline { 2 - 4 }
\end{tabular}} & Yes & 20 & 14.8 \\
\hline \multirow{2}{*}{$\begin{array}{l}\text { Hormone } \\
\text { therapy }\end{array}$} & Sim & 15 & 42.1 \\
\hline \multirow{2}{*}{ Radiotherapy } & Yl* & 10 & 41.4 \\
\cline { 2 - 4 } & No & 14 & 28.6 \\
\hline
\end{tabular}

Therapeutic approach used in cases of invasive lobular carcinoma treated at HC-UFPR between 2005 and 2014; *not informed.

Table 4. Imaging examinations.

\begin{tabular}{|c|c|c|c|}
\hline & BIRADS & $\begin{array}{l}\text { Absolute } \\
\text { frequency }\end{array}$ & $\begin{array}{c}\text { Relative } \\
\text { frequency (\%) }\end{array}$ \\
\hline \multirow{8}{*}{ US } & 0 & 2 & 10.5 \\
\hline & 1 & 0 & 0 \\
\hline & 2 & 0 & 0 \\
\hline & 3 & 0 & 0 \\
\hline & 4 & 8 & 42.1 \\
\hline & 5 & 8 & 42.1 \\
\hline & 6 & 0 & 0 \\
\hline & $N I^{*}$ & 1 & 5.2 \\
\hline \multirow{7}{*}{ MMG } & 0 & 1 & 5.2 \\
\hline & 1 & 0 & 0 \\
\hline & 2 & 0 & 0 \\
\hline & 3 & 1 & 5.2 \\
\hline & 4 & 12 & 63.1 \\
\hline & 5 & 5 & 26.3 \\
\hline & 6 & 0 & 0 \\
\hline
\end{tabular}

Data on imaging results in cases of invasive lobular carcinoma treated at HC-UFPR between 2005 and 2014; *not informed; MMG: mammography

The use of conservative surgery followed by adjuvant radiotherapy is a well-accepted therapeutic modality for ductal invasive breast cancers, but it is controversial when considered for ILC $^{24}$ due to the high rates of multifocality and multicentricity in ILC, which often involve compromised surgical margins requiring new therapy ${ }^{20}$. This can possibly explain the fact that, in our study, the surgical therapeutic modality applied in more than $70 \%$ of patients was radical mastectomy. Despite the increase 


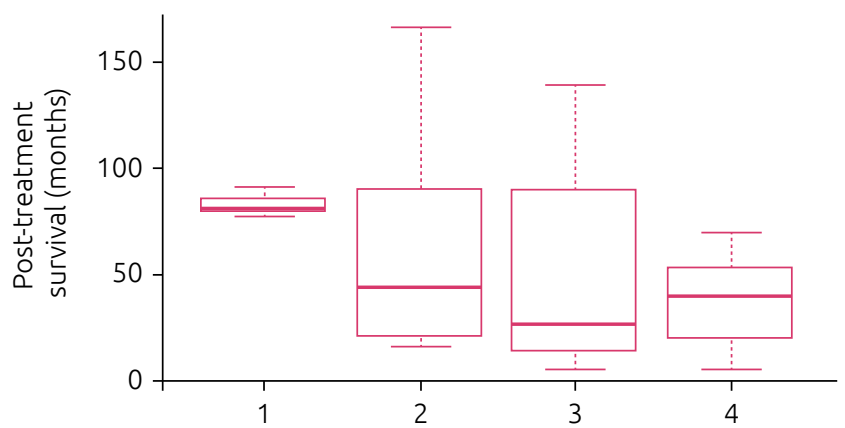

B

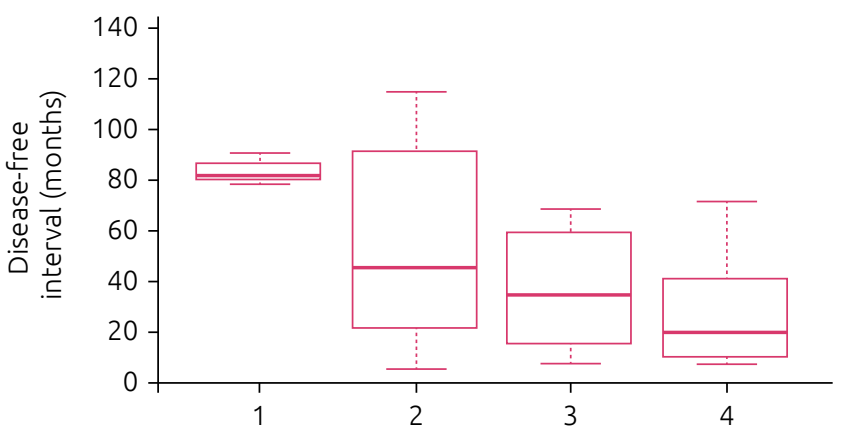

Correlation between post-treatment survival and disease-free interval versus clinical stage of patients treated for invasive lobular carcinoma at HC-UFPR between 2005 and 2014. Kruskal-Wallis test, $p=0.7193$ (A) and $p=0.1202(B)$. Comparison between stages 1 and 4 only, $p=0.002$ ( $A$ ) and $p=0.001$ (B). Graph 2. Correlation between post-treatment survival and disease-free interval. clinical stage.

A

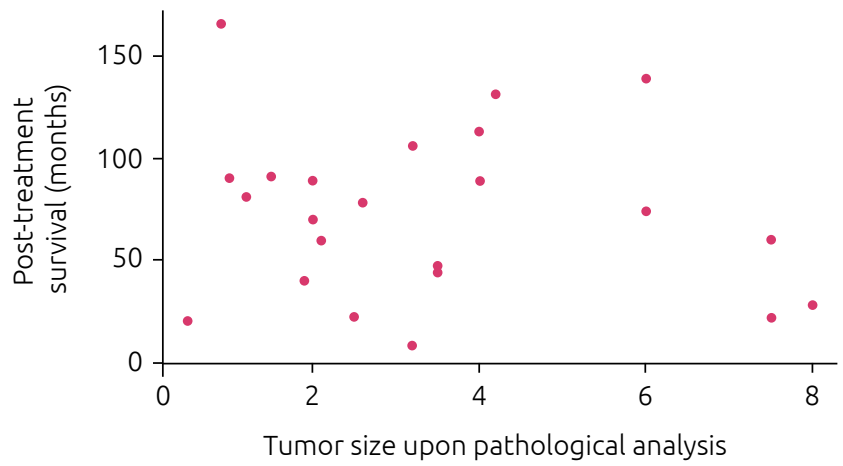

B

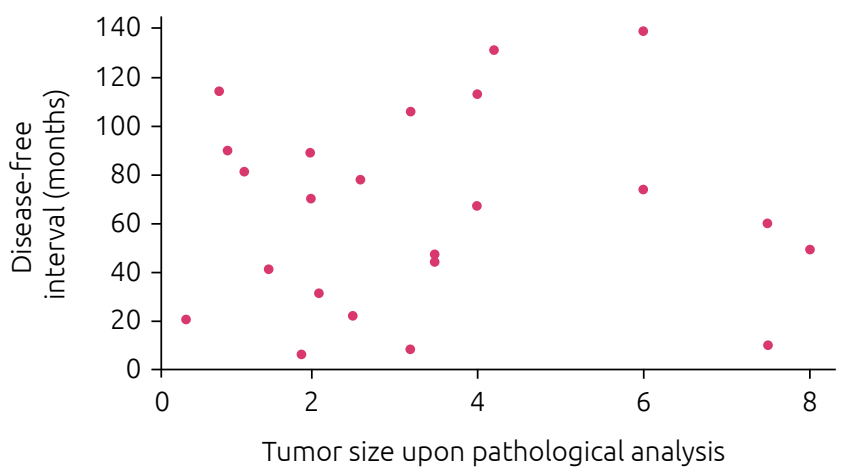

Correlation between post-treatment survival and disease-free interval versus tumor size in anatomopathological analysis of patients treated for invasive lobular carcinoma at HC-UFPR between 2005 and 2014. Spearman's correlation test, $p=0.7193$ (A) and p=0.7449 (B).

Graph 3. Correlation between post-treatment survival and disease-free interval versus tumor size in anatomopathological analysis.

in indications for non-radical surgical therapies, mastectomy remains the main option due to this pattern of multifocality and discreet infiltration by the breast tissue, which is difficult for the surgeon to identify ${ }^{25}$. Among patients assessed in our study, 21 were submitted to radiotherapy and only eight of them to conservative surgery, suggesting that some patients underwent radiotherapy for other indications such as metastatic lesions and disease recurrence.

Regarding axillary lymph node approach, our study found a predominance of axillary emptying as the initial therapy (62.9\%), which can be attributed to the difficulty of detecting metastatic ILC cells in lymph nodes because they present in isolation between the lymphocyte cells of the lymph node itself, particularly in micro-metastases, hence the preference for radical surgi$\mathrm{cal}^{26}$. There is now evidence that axillary emptying is not better

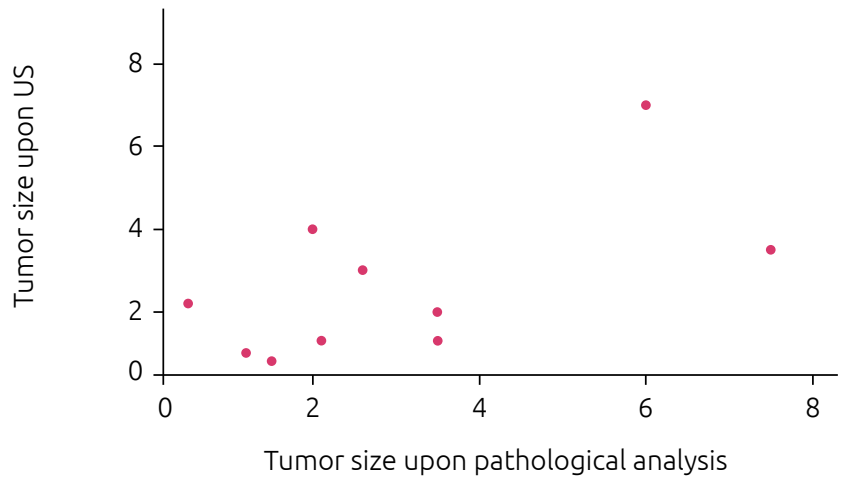

Correlation between tumor size upon US and tumor size upon anatomopathological analysis of invasive lobular carcinomas treated at HC-UFPR between 2005 and 2014. Spearman's correlation test, $p=0.156$.

Graph 4. Correlation between tumor size upon US and tumor size in anatomopathological analysis. 
than conservative sentinel lymph node treatment with regard to locoregional recurrence ${ }^{27}$.

ILC usually has unsatisfactory response to chemotherapy and HER2-targeted therapy because of its negativity for this marker. However, hormone therapy centered on ER and PR positivity, typical of ILC, is highly indicated as adjuvant therapy capable of improving survival ${ }^{28}$. In our study, $71.4 \%$ of patients underwent hormone therapy, in contrast to $90 \%$ ER positive and $70 \%$ PR positive. We believe that the lack of information in medical records may be associated with the high rate of patients who did not receive this adjuvant treatment option; that is, the rest of the patients would also have received HT but data were not input in medical records. Nevertheless, previous studies have shown that patients with invasive lobular carcinoma receive less hormonal therapy than recommended ${ }^{28}$.

The clinical staging of patients was compared to DFI and posttreatment survival. In both cases, associations were not statistically significant when all clinical stages were compared simultaneously. However, when stages I and IV were compared, there was a significant difference, which shows that both post-treatment survival and DFI were negatively impacted by advanced staging. Stages II and III not being significantly associated can be explained by the small number of samples obtained in our study and by some patients being lost to follow-up over the course of the 10 years studied.

The size of the tumor in the anatomopathological biopsy also had no significant association with DFI and post-treatment survival. Again, we attribute this the reduced number of cases in the sample and to losses of follow-up. Another similar study carried out in a Brazilian university hospital reported significant results for this association, which shows that the larger the tumor, the worse patients' survival ${ }^{23}$.

With regard to imaging tests, only one exam was predominant $(45.7 \%)$ in relation to the performance of US and mammography in combination (31.4\%). The sensitivity of these two tests is controversial in the literature, varying from 57 to $89 \%$ for mammography and from 71 to $91 \%$ for US ${ }^{22,29}$. Because of this variability, complementing diagnosis with another imaging test in cases of greater suspicion is important to reduce errors. For an appropriate therapeutic approach to ILC, it is essential that the disease is staged correctly, and both US and mammography have shown high rates of underestimation of tumor size, as well as failures in ILC detection by mammography screening because of the similarity of tumor density with the adjacent mammary parenchyma ${ }^{30}$. MRI, therefore, plays a key role in ILC detection and staging definition, with a $93.3 \%$ sensitivity ${ }^{29}$. Unfortunately, in our series, none of the patients were referred to MRI, which exposes a deficiency of the health system in providing patients with adequate access to existing resources.

The discrepancy in size of ILC tumors in imaging and pathological analysis has been described in several studies, which suggests an underestimation of tumor size by mammography and US when compared to its actual size measured in postsurgical biopsies. Mammography has an average of $12 \mathrm{~mm}$ of underestimation, while in US it varies from 5.4 to $12.2 \mathrm{~mm}^{29.30}$. MRI, however, has a correlation index with pathology of 0.8-0.97, proving to be much more reliable for the purpose of measuring ILC tumor size ${ }^{29}$. In our study, we did not find a significant relationship between tumor size upon US and pathological anatomy $(\mathrm{p}=0.156)$. We attribute this the very small number of patients whose medical records contained this information, resulting in a very small sample for statistical analysis.

\section{CONCLUSIONS}

Our study reflects the reality of a South-Brazilian university hospital with data encompassing 10 years of medical records, which shows that the clinical-epidemiological features of patients treated for ILC at HC-UFPR are in accordance with the literature, both in incidence and in characteristics of tumors. The evaluation of ILC dimensions in imaging examinations compared to the real size of lesions identified in postoperative specimens resulted not statistically significant. We had great limitation of access to clinical data of patients due to the lack of information in medical records. This study is important because it not only depicts ILC's epidemiology in a South Brazilian hospital, but also shows the need for early diagnosis and correct use of diagnostic resources to achieve this goal.

\section{REFERENCES}

1. Instituto Nacional de Cancer José Alencar Gomes da Silva. Estimativa 2016. Brasil: Ministério da Saúde; 2016.

2. Ferlay J, Soerjomataram I, Ervik M, Dikshit R, Eser S, Mathers C, et al. GLOBOCAN 2012 v1.0, Cancer incidence and mortality worldwide: IARC cancerbase. cancer incidence and mortality worldwide. IARC Cancer Base; 2014.

3. Li CI, Uribe DJ, Daling JR. Clinical characteristics of different histologic types of breastcancer.BrJCancer.2005;93(9):1046-52. https://dx.doi.org/10.1038\%2Fsj.bjc.6602787
4. Dossus L, Benusiglio PR. Lobular breast cancer: incidence and genetic and non-genetic risk factors. Breast Cancer Res. 2015;17:37. https://doi.org/10.1186/s13058-015-0546-7

5. Eheman CR, Shaw KM, Ryerson AB, Miller JW, Ajani UA, White $\mathrm{MC}$. The changing incidence of in situ and invasive ductal and lobular breast carcinomas: United States, 1999-2004. Cancer Epidemiol Biomarkers Prev. 2009;18(6):1763-9. https://doi. org/10.1158/1055-9965.EPI-08-1082 
6. Rossouw JE, Anderson GL, Prentice RL, LaCroix AZ, Kooperberg C, Stefanick ML, et al. Risks and Benefits of Estrogen Plus Progestin in Healthy Postmenopausal Women. J Am Med Assoc. 2012;288(3):321-33.

7. Wachtel MS, Yang S, Dissanaike S, Margenthaler JA. Hormone replacement therapy, likely neither angel nor demon. PLoS One. 2015;10(9):e0138556. https://doi.org/10.1371/journal. pone.0138556

8. Christgen M, Steinemann D, Kühnle E, Länger F, Gluz O, Harbeck N, et al. Lobular breast cancer: Clinical, molecular and morphological characteristics. Pathol Res Pract. 2016;212(7):583-97. https://doi.org/10.1016/j.prp.2016.05.002

9. Allen-Brady K, Camp NJ, Ward JH, Cannon-Albright LA. Lobular breast cancer: Excess familiality observed in the Utah Population Database. Int J Cancer. 2005;117(4):655-61. https:// doi.org/10.1002/ijc.21236

10. Li CI, Daling JR, Haugen KL, Tang MTC, Porter PL, Malone KE. Use of menopausal hormone therapy and risk of ductal and lobular breast cancer among women 55-74 years of age. Breast Cancer Res Treat. 2014;145(2):481-9. https://doi.org/10.1007/ s10549-014-2960-4

11. Newcomb PA, Trentham-Dietz A, Hampton JM, Egan KM, Titus-Ernstoff L, Warren Andersen S, et al. Late age at first full term birth is strongly associated with lobular breast cancer. Cancer. 2011;117(9):1946-56. https://dx.doi. org/10.1002\%2Fcncr.25728

12. Li CI, Malone KE, Porter PL, Weiss NS, Tang MTC, Daling JR. Reproductive and anthropometric factors in relation to the risk of lobular and ductal breast carcinoma among women 65-79 years of age. Int J Cancer. 2003;107(4):647-51. https://doi. org/10.1002/ijc.11465

13. Sharma SDJ, Barry M, O’Reilly EA, Kell MR. Surgical management of lobular carcinoma from a national screening program: a retrospective analysis. Eur J Surg Oncol. 2015;41(1):79-85. https://doi.org/10.1016/j.ejso.2014.09.004

14. Lee J-H, Park S, Park HS, Park B-W. Clinicopathological features of infiltrating lobular carcinomas comparing with infiltrating ductal carcinomas: a case control study. World J Surg Oncol. 2010;8:34. https://doi.org/10.1186/1477-7819-8-34

15. Arpino G, Bardou VJ, Clark GM, Elledge RM. Infiltrating lobular carcinoma of the breast: tumor characteristics and clinical outcome. Breast Cancer Res. 2004;6(3):R149-56. https://dx.doi.org/10.1186\%2Fbcr767

16. Sastre-Garau X, Jouve M, Asselain B, Vincent-Salomon A, Beuzeboc P, Dorval T, et al. Infiltrating lobular carcinoma of the breast: Clinicopathologic analysis of 975 cases with reference to data on conservative therapy and metastatic patterns. Cancer. 1996;77(1):113-20. https://doi. org/10.1002/(SICI)1097-0142(19960101)77:1\%3C113::AIDCNCR19\%3E3.0.CO;2-8

17. Sinclair K, Sakellariou S, Dawson N, Litherland J. Does preoperative breast MRI significantly impact on initial surgical procedure and re-operation rates in patients with screen-detected invasive lobular carcinoma? Clin Radiol. 2016;71(6):543-50. https://doi.org/10.1016/j.crad.2016.03.011

18. Smith DB, Howell A, Wagstaff J. Infiltrating lobular carcinoma of the breast: Response to endocrine therapy and survival. Eur J Cancer Clin Oncol. 1987;23(7):979-82.
19. Dutra MC, Rezende MA, de Andrade VP, Soares FA, Ribeiro MV, de Paula EC, et al. Imunofenótipo e evolução de câncer de mama: comparação entre mulheres muito jovens e mulheres na pós-menopausa. Rev Bras Ginecol Obs. 2009;31(2):54-60. http://dx.doi.org/10.1590/S0100-72032009000200002

20. Biglia N, Mariani L, Sgro L, Mininanni P, Moggio G, Sismondi P. Increased incidence of lobular breast cancer in women treated with hormone replacement therapy: implications for diagnosis, surgical and medical treatment. Endocr Relat Cancer. 2007;14(3):549-67. https://doi.org/10.1677/ ERC-06-0060

21. Zhu MZ, Yu XF, He XM, Feng WL, Fan JH, Li J, et al. Clinicopathological features of invasive lobular carcinoma of the breast: a nationwide multicenter study in China. J Cancer Res Ther. 2015;11(Supl. 1):C89-94. https://doi.org/10.4103/09731482.163851

22. Winchester DJ, Chang HR, Graves TA, Menck HR, Bland KI, Winchester DP. A comparative analysis of lobular and ductal carcinoma of the breast: presentation, treatment, and outcomes. J Am Coll Surg. 1998;186(4):416-22.

23. Gomes, DS. Aspectos clínicos, anátomo-patológicos e evolutivos de uma série de lesões lobulares da mama tratadas em uma mesma instituição [dissertation]. Belo Horizonte: Federal University of Minas Gerais. Medicine School; 2010;

24. Peiro G, Bornstein BA, Connolly JL, Gelman R, Hetelekidis S, Nixon AJ, et al. The influence of infiltrating lobular carcinoma on the outcome of patients treated with breast-conserving surgery and radiation therapy. Breast Cancer Res Treat. 2000;59(1):49-54.

25. Dillon MF, Hill ADK, Fleming FJ, O’Doherty A, Quinn $\mathrm{CM}$, McDermott EW, et al. Identifying patients at risk of compromised margins following breast conservation for lobular carcinoma. Am J Surg. 2006;191(2):201-5. https://doi. org/10.1016/j.amjsurg.2005.03.041

26. Salles MDA, Cúrcio VS, Perez AA, Gomes DS, Gobbi H. Contribuição da imuno-histoquímica na avaliação de fatores prognósticos e preditivos do câncer de mama e no diagnóstico de lesões mamárias. J Bras Patol e Med Lab. 2009;45(3):213-22. http://dx.doi.org/10.1590/S1676-24442009000300006

27. Giuliano AE, Ballman K, McCall L, Beitsch P, Whitworth PW, Blumencranz P, et al. Locoregional Recurrence After Sentinel Lymph Node Dissection With or Without Axillary Dissection in Patients With Sentinel Lymph Node Metastases. Ann Surg. 2016;264(3):413-20. https://doi.org/10.1097/ SLA.0000000000001863

28. Rakha EA, El-Sayed ME, Powe DG, Green AR, Habashy H, Grainge MJ, et al. Invasive lobular carcinoma of the breast: response to hormonal therapy and outcomes. Eur J Cancer. 2008;44(1):73-83. https://doi.org/10.1016/j.ejca.2007.10.009

29. Mann RM, Hoogeveen YL, Blickman JG, Boetes C. MRI compared to conventional diagnostic work-up in the detection and evaluation of invasive lobular carcinoma of the breast: a review of existing literature. Breast Cancer Res Treat. 2008 Jan;107(1):1-14. https://dx.doi. org/10.1007\%2Fs10549-007-9528-5

30. Yeatman TJ, Cantor AB, Smith TJ, Smith SK, Reintgen DS, Miller MS, et al. Tumor biology of infiltrating lobular carcinoma. Implications for management. Ann Surg. 1995;222(4):549-61. 